Volume 2 Nomor 2, November 2021: h. 140 - 151 P-ISSN: 2722-4465, E-ISSN: 2746-8151

Lisensi Creative Commons Atribusi-NonCommercial 4.0 Internasional

\title{
Pelaksanaan Eksekusi Benda Bergerak Yang Tidak Dibebani Jaminan Fidusia Di Perkoperasian
}

\section{IM Arjaya $1^{*}$, Nyoman Putra Suhambara ${ }^{2}$}

1, 2, Fakultas Hukum Universitas Warmadewa, Denpasar, Indonesia

E-mail: imd.arjaya@gmail.com

\begin{tabular}{l}
\multicolumn{1}{c}{ Dikirim: 19/09/2021 } \\
\hline Info Artikel \\
\hline Keywords: \\
Execution; Guarantee; \\
Fiduciary. \\
\hline Kata Kunci: \\
Eksekusi; Jaminan; Fidusia.
\end{tabular}

\begin{abstract}
Guarantee execution is one of the ways when the debtor is negligent in carrying out his obligations which are carried out in accordance with applicable legal procedures. Furthermore, two basic problems are formulated to be studied, namely: 1). How is the execution of movable objects that are not burdened with Fiduciary Guarantees? And 2). What legal efforts can be made by the creditor if the execution of movable objects that are not burdened? this section also describes the purpose and benefits of writing and the originality of research as the work of the real writer. This study uses an empirical juridical approach, data obtained through library research and direct research in the field. Based on the results of the study, it can be concluded that. Judging from the law enforcement theory, the execution of collateral objects with fiduciary guarantees at the Cooperative, namely when the debtor is declared default, the cooperative will seize the object of collateral, takeover or disbursement of collateral objects under the hand, and auction the guarantee object based on the Selling Power. And the creditor's legal efforts according to the theory of legal protection cannot be implemented, namely the cooperative as the creditor will take a nonlitigation path such as negotiation and mediation. And if the nonlitigation path does not produce results, the cooperative will take a litigation route, namely to file a lawsuit to the court on the basis of a default made by the debtor.
\end{abstract}


DOI:

10.47268/ballrev.v2i2.689 disimpulkan bahwa: Dilihat dari teori penegakan hukum, pelaksanaan eksekusi benda jaminan dengan jaminan fidusia pada Koperasi, yakni ketika debitur dikatakan wanprestasi, maka pihak koperasi akan melakukan penyitaan terhadap objek jaminan, pengambilalihan atau pencairan objek jaminan secara dibawah tangan, serta pelelangan terhadap objek jaminan berdasarkan Surat Kuasa Menjual. Dan upaya hukum kreditur menurut teori perlindungan hukum jika tidak dapat dilaksanakan secara damai yaitu pihak koperasi selaku kreditur akan menempuh jalur non litigasi seperti negosiasi dan mediasi. Dan apabila jalur non litigasi tersebut tidak membuahkan hasil maka pihak koperasi akan menempuh jalur litigasi yakni mengajukan gugatan ke pengadilan atas dasar wanprestasi yang dilakukan oleh debitur.

\section{Pendahuluan}

Koperasi sebagai suatu badan usaha yang berbadan hukum dapat melaksanakan kegiatan usaha simpan pinjam sebagai salah satu usaha atau satusatunya kegiatan usaha koperasi (Kurniawan, 2013), dalam pasal 44 UU Perkoperasian khususnya koperasi simpan pinjam dalam kegiatan usahanya adalah menerima tabungan atau menghimpun dana serta menyalurkannya kembali, dana tersebut berasal dari dan untuk anggota koperasi lainnya. Oleh karena itu pinjaman wajib dikelola dengan prinsip kehati-hatian (Prudential) (Zaeni, 2005).

Pemberian pinjaman oleh Koperasi Simpan Pinjam, sebagaimana dilakukan pada pemberian kredit bank, ada beberapa hal yang harus diperhatikan dalam rangka melindungi dan mengamankan dana masyarakat yang dikelola Koperasi Simpan Pinjam untuk disalurkan dalam bentuk pinjaman (Wibowo, 2013), yaitu

1) Harus dilakukan dengan menggunakan prinsip kehati-hatian;

2) Harus mempunyai keyakinan atas kemampuan dan kesanggupan debitur (dalam perjanjian pinjaman untuk koperasi disebut dengan anggota) untuk melunasi hutangnya sesuai dengan yang diperjanjikan;

3) Wajib menempuh cara-cara yang tidak merugikan lembaga dan masyarakat yang mempercayakan dananya pada Koperasi Simpan Pinjam;

4) Harus memperhatikan asas-asas perkreditan yang sehat.

Dalam hal pemberian pinjaman yang diberikan oleh Koperasi, khususnya kepada anggotanya, membebankan benda sebagai jaminan, yang umumnya penguasaan debiturnya karena dapat dipergunakan untuk beraktivitas dalam kehidupan sehari-hari atas dasar kepercayaan dari Koperasi kepada anggotanya.

Pemberian jaminan oleh pihak kreditur kepada nasabah atau anggotanya didasarkan atas kepercayaan, dan apabila debiturnya wanprestasi maka tindakan yang dilakukan koperasi adalah dengan melakukan eksekusi benda jaminan tersebut (Wahyuni, 2011), dengan kata lain, apabila konsumen (debitur) melalaikan kewajibannya atau cidera janji yang berupa lalainya konsumen memenuhi kewajibannya pada saat pelunasan utangnya yang sudah waktunya untuk ditagih, maka kreditur dapat melaksanakan eksekusi atas benda Jaminan Fidusia 
(Manurung, 2015). Mengenai eksekusi Jaminan Fidusia diatur dalam Pasal 29 ayat (1) UUJF yang menyebutkan apabila debitur atau konsumen cidera janji, eksekusi terhadap Benda yang menjadi obyek Jaminan Fidusia dapat dilakukan dengan cara:

1) Pelaksanaan titel eksekutorial sebagaimana dimaksud dalam Pasal 15 ayat (2) oleh Penerima Fidusia;

2) Penjualan Benda yang menjadi obyek Jaminan Fidusia atas kekuasaan penerima fidusia sendiri melalui pelelangan umum serta mengambil pelunasan piutangnya dari hasil penjualan;

3) Penjualan dibawah tangan yang dilakukan berdasarkan kesepakatan Pemberi dan koperasi jika dengan cara demikian dapat diperoleh harga tertinggi yang menguntungkan para pihak.

UUJF telah memberikan aturan mengenai pelaksanaan eksekusi atas objek Jaminan Fidusia, namun faktanya di lapangan pelaksanaan eksekusi yang dilakukan oleh koperasi tidak mematuhi aturan perundang-undangan yang berlaku (Widjaja \& Yani, 2000). Koperasi melakukan eksekusi sesuai dengan jaminan fidusia yang telah didaftarkan, sedangkan koperasi sendiri hanya melakukan perjanjian fidusia secara di bawah tangan. Mengenai pembebanan jaminan dengan jaminan fidusia diatur dalam Pasal 11 ayat (1) UUJF yaitu: "benda yang dibebani dengan jaminan fidusia wajib didaftarkan"

Koperasi juga dapat ditemukan tidak melakukan kontrak perjanjian pinjaman dengan debitur dihadapan notaris, sehingga perjanjian tersebut hanya mempunyai kekuatan pembuktian sebagai perjanjian dibawah tangan karena tidak ada akta notaris sebagai kekuatan hukum atas perjanjian tersebut (Fuady, 2014). Pelanggaran dengan dibuatnya perjanjian pinjaman secara dibawah tangan, koperasi tidak mendaftarkan Jaminan Fidusia yang diberikan kepada kantor pendaftaran Jaminan Fidusia untuk kemudian mendapatkan sertifikat Jaminan Fidusia. Sementara itu, dalam UUJF dan PP No. 21 Tahun 2015 tentang Tata Cara Pendaftaran Fidusia dan Biaya Pendaftaran Fidusia, Tambahan Lembaran Negara Republik Indonesia Nomor 5691 (untuk selanjutnya disebut tata cara pendaftaran fidusia) disebutkan salah satu syarat pendaftaran Fidusia adalah adanya salinan Akta Notaris yang disebutkan di atas, dengan demikian perjanjian yang dibuat dibawah tangan tanpa akta notaris maka tidak dapat dibuatkan sertifikat fidusia (Bahsan, 2012). Pelanggaran yang dilakukan oleh koperasi ini tentu berdampak pada perlindungan hukum dan penegakan hukum dari perjanjian Jaminan Fidusia yang dilakukan oleh koperasi dengan pihak debitur selaku konsumen (Nasution, 2014).

Akibat dari Jaminan Fidusia yang tidak dibuatkan sertifikat fidusianya maka objek Jaminan Fidusia tersebut tidak mempunyai hak eksekusi langsung. Pada saat terjadi wanprestasi atau kemacetan dari konsumen, maka pihak koperasi tidak dapat melakukan eksekusi terhadap objek jaminan tersebut. Akan tetapi koperasi melakukan penjualan dibawah tangan yang dilakukan berdasarkan kesepakatan debitur dan koperasi. Apabila dengan cara demikian dapat diperoleh harga tertinggi yang menguntungkan para pihak. Eksekusi tersebut tertuang dalam jaminan fidusia 
yang sudah terdaftarkan, tetapi disini koperasi hanya melakukan secara di bawah tangan saja.

\section{Metode Penelitian}

Pada penelitian Hukum ini menggunakan penelitian hukum Empiris karena adanya kesenjangan norma pada ketentuan Pasal 11 Undang-Undang No 42 Tahun 1999 tentang Jaminan Fidusia bahwa "benda yang dibebani dengan jaminan fidusia wajib didaftarkan" akan tetapi di dalam prakteknya koperasi tidak mendaftarkan jaminan fidusia dan hanya membuat secara dibawah tangan (Adiyanta, 2019).

\section{Hasil dan Pembahasan}

\subsection{Penegakan Hukum Pelaksanaan eksekusi jaminan benda bergerak yang tidak dibebani dengan jaminan fidusia terhadap perkoperasian di Denpasar}

Keberadaan Undang-Undang Nomor 42 Tahun 1999 tentang Jaminan Fidusia. Umumnya perjanjian pembebanan atau pengikatan suatu benda untuk menjadi objek jaminan, didahului dengan pembuatan perjanjian utang piutang (perjanjian pinjaman atau perjanjian pokoknya), lalu diikuti dengan perjanjian pengikatan jaminan utang atau perjanjian pembebanan benda sebagai objek jaminan yang dibuat secara terpisah, yang merupakan perjanjian assesoir.

Wanprestasi adalah suatu keadaan dimana debitor tidak memenuhi janjinya atau tidak memenuhi sebagaimana mestinya dan kesemuanya itu dapat dipersalahkan kepadanya (Marbun et al., 2015). Perkataan wanprestasi berasal dari bahasa Belanda, yang berarti prestasi buruk. Debitur tidak melaksanakan yang dijanjikannya, atau lalai dan melanggar perjanjian maka ia telah melakukan wanprestasi (Patrik, 1998). Wanprestasi (kelalaian atau kealpaan) seorang debitur, bentuknya berupa:

a) Tidak melakukan apa yang disanggupi untuk dilakukannya;

b) Melaksanakan apa yang dijanjikannya, tetapi tidak sebagaimana dijanjikan;

c) Melakukan apa yang dijanjikan tetapi terlambat;

d) Melakukan sesuatu yang menurut perjanjian tidak boleh dilakukannya.

Berdasarkan keterangan dari Bapak I Ketut Taman (Ketua Koperasi Keluarga Buaji Anyar), menerangkan bahwa pembebanan benda khusunya benda bergerak seperti kendaraan bermotor berdasarkan kepercayaan dengan Jaminan Fidusia dalam pemberian pinjaman di Koperasi Simpan Pinjam Keluarga Buaji Anyar, dilakukan dengan perjanjian dibawah tangan (akta dibawah tangan), tidak dengan akta notaris (akta otentik). Pembebanan objek jaminan dalam rangka pemberian pinjaman di Koperasi Simpan Pinjam Keluarga Buaji Anyar dilakukan tidak dengan pembuatan perjanjian yang terpisah dari perjanjian pokoknya, akan tetapi menyatu dengan perjanjian pokoknya, dengan mencantumkan klausula mengenai penyerahan benda sebagai objek jaminan, disertai dengan kuasa penuh kepada Koperasi Simpan Pinjam Keluarga Buaji Anyar untuk menjual objek jaminan apabila dikemudian hari debitur tidak dapat melunasi utangnya dalam kurun waktu yang sebelumnya telah disepakati antara Koperasi Simpan Pinjam Keluarga Buaji Anyar 
sebagai kreditur dengan debitur. Selanjutnya, pembebanan kendaraan bermotor sebagai jaminan di Koperasi Simpan Pinjam Keluarga Buaji Anyar dilakukan dengan penyimpanan terhadap dokumen kepemilikan kendaraan bermotor berupa BPKB yang akan disimpan oleh Koperasi Simpan Pinjam Keluarga Buaji Anyar sampai saat pinjaman dilunasi oleh debitur. Oleh Koperasi Simpan Pinjam Keluarga Buaji Anyar akan dikeluarkan surat tanda terima penyerahan jaminan berupa Bukti Penerimaan

Jaminan Koperasi Simpan Pinjam Keluarga Buaji Anyar dan dilakukan pencatatannya oleh Koperasi Simpan Pinjam Keluarga Buaji Anyar.

Lebih lanjut keterangan Bapak I Ketut Taman (Ketua Koperasi Keluarga Buaji Anyar) menerangkan bahwa, apabila surat peringatan (SP) II tidak ditanggapi maka, akan dilakukan pendekatan pengurus dan badan pengawas. Koperasi Simpan Pinjam Keluarga Buaji Anyar akan melakukan penyitaan terhadap objek jaminan, pengambilalihan atau pencairan objek jaminan (khususnya objek jaminan benda bergerak berupa motor atau mobil) secara dibawah tangan, serta pelelangan terhadap objek jaminan berdasarkan Surat Kuasa Menjual yang merupakan satu kesatuan dengan perjanjian pinjaman yang tidak dapat dipisahkan, dengan cara menjual objek jaminan secara langsung. Hasil penjualan setelah dikurangi biayabiaya untuk melaksanakan penjualan tersebut, menggunakan sisanya untuk membayar utang debitur kepada Koperasi Simpan Pinjam Keluarga Buaji Anyar, dan apabila ada kelebihan maka Koperasi Simpan Pinjam Keluarga Buaji Anyar akan menyerahkan atau mengembalikan kelebihan tersebut kepada debitur. Hal tersebut sesuai dengan apa yang tertuang di dalam Perjanjian Pinjaman yang telah disepakati antara kreditur dan debitur.

\subsection{Upaya Hukum Yang Dapat Dilakukan Kreditur Jika Eksekusi Terhadap Benda Bergerak Yang Tidak Dibebani Jaminan Fidusia Tidak Dapat Dilaksanakan Terhadap Perkoperasian Di Denpasar}

Pembebanan jaminan fidusia dalam aspek operasionalnya dilaksanakan melalui dua tahap, yaitu tahap pemberian jaminan fidusia dan tahap pendaftaran fidusia. Pembebanan jaminan fidusia yang didahului dengan janji untuk memberikan jaminan fidusia sebagai pelunasan atas hutang tertentu yang dituangkan dalam akta jaminan fidusia.

Akta dibawah tangan bukanlah akta otentik yang memiliki nilai pembuktian yang sempurna. Sebaliknya akta otentik adalah akta yang dibuat oleh dan atau dihadapan pejabat yang yang ditunjuk oleh undang-undang dan memiliki kekuatan hukum yang sempurna. Akan tetapi suatu akta dibawah tangan tetap memiliki kekuatan bukti hukum sepanjang para pihak mengakui keberadaan dan isi akta tersebut seperti halnya mengenai objek jaminan, dan lain sebagainya (Prodjodikoro, 2004).

Pembebanan benda sebagai objek jaminan, khususnya benda bergerak berupa motor dan mobil di Koperasi pengikatannya atau pembebanannya dilakukan dengan membuat perjanjian yang terpisah dari perjanjian pokoknya, yaitu dengan cara pencantuman klausula dalam perjanjian pinjaman mengenai penyerahan jaminan secara kepercayaan, dan penguasaan tanda bukti kepemilikan objek jaminan (Agnes, 
2009), dengan demikian, kekuatan akta jaminan fidusia yang tidak didaftarkan oleh Pihak Koperasi, maka kedudukan Koperasi hanya sebagai kreditur konkuren yaitu kreditur yang tidak memiliki hak untuk didahulukan terhadap kreditur lainnya, apabila debitur memiliki lebih dari 1 (satu) kreditur (Setyorini, 2017). Koperasi hanya akan dijamin dengan jaminan umum sebagaimana dimaksud dalam Pasal 1131 dan 1132 Kitab Undang-Undang Hukum Perdata. Hal tersebut juga bukan berarti Koperasi tidak memiliki hak jaminan atas pelunasan piutangnya, akan tetapi dijamin dengan seluruh harta kekayaan milik debitur yang akan menjadi jaminan pelunasan utang debitor terhadap semua kreditur. Dengan jaminan umum, kreditur tidak dapat mengetahui secara jelas harta kekayaan debitur yang ada sekarang maupun yang ada dikemudian hari, serta kepada siapa saja debitur berhutang, sehigga khawatir hasil penjualan harta kekayaan debitur nantinya tidak cukup untuk melunasi utangutangnya. Untuk itu kreditur memerlukan adanya benda-benda tertentu yang digunakan sebagai jaminan lain untuk melunasi hutang dari debitur apabila debitur tidak dapat melunasi hutangnya.

Akibat hukum dalam suatu perjanjian yang dilakukan akan terlihat ketika salah satu pihak melakukan tindakan wanprestasi dan merugikan pihak lain. Pihak yang dirugikan umumnya meminta pihak yang melakukan wanprestasi untuk mengganti kerugian yang diderita. Tuntutan ganti rugi yang dilakukan oleh kreditor antara lain menyangkut penggantian biaya, rugi dan bunga (Slamet, 2013).

Koperasi dalam hal melakukan perjanjian khususnya perjanjian dengan jaminan fidusia memiliki resiko yang cukup besar, diantaranya kerugian yang akan dialami jika terjadi wanprestasi yang dilakukan oleh debitor. Pada kasus wanprestasi yang dilakukan debitor-debitor pada Koperasi yang menimbulkan kerugian terhadap kreditor, penyelesaian sengketanya pertama-tama dilakukan dengan cara memberikan peringatan berupa teguran, kemudian dilanjutkan dengan memberikan surat peringatan kepada debitor, namun jika debitor tetap tidak memenuhinya maka kreditor dapat melakukan tindakan selanjutnya yaitu melalui upaya hukum non litigasi dan litigasi.

Penyelesaian sengketa dengan upaya hukum non litigasi maksudnya adalah dalam menyelesaikan permasalahan yang terjadi antara kreditor dengan debitor dilakukan dengan cara negosiasi dan mediasi, sedangkan dengan cara litigasi maksudnya adalah pihak kreditor melakukan gugatan terhadap debitor melalui peradilan yang berada di lingkungan peradilan umum.

a. Penyelesaian sengketa dengan cara non litigasi

Penyelesaian sengketa dengan cara non litigasi merupakan penyelesaian sengketa di luar pengadilan (Sembiring, 2011). Penyelesaian sengketa melalui proses di luar pengadilan menghasilkan kesepakatan yang bersifat win- win solution atau saling menguntungkan satu sama lain yang dijamin kerahasiaan sengketa para pihak, dihindari kelambatan yang diakibatkan karena hal prosedural dan administratif, menyelesaikan masalah secara komprehensif dalam kebersamaan dan tetap menjaga hubungan baik. Kelebihan proses non litigasi ini terletak pada sifat 
kerahasiaannya, karena proses persidangan dan bahkan hasil keputusannya pun tidak dipublikasikan.

Landasan hukum penyelesaian sengketa dengan cara non litigasi yaitu: Pasal 1338 KUHPerdata yang menyatakan bahwa semua perjanjian yang dibuat secara sah, berlaku sebagai undang-undang bagi yang membuatnya. Ketentuan ini mengandung asas perjanjian bersifat terbuka, artinya, dalam menyelesaikan masalah, setiap orang bebas memformulasikannya dalam bentuk perjanjian yang isinya apapun untuk dapat dijalankan dalam rangka menyelesaikan masalah, selanjutnya sebagaimana ditentukan dalam Pasal 1340 KUHPerdata bahwa perjanjian hanya berlaku antara pihak-pihak yang membuatnya.

Penyelesaian sengketa dengan cara non litigasi membuat ketentuan tersebut menjadi penting dalam hal mengingatkan kepada para pihak yang bersengketa bahwa kepadanya diberikan kebebasan oleh hukum untuk memilih jalan dalam menyelesaikan masalahnya yang dapat dituangkan dalam perjanjian, asal perjanjian itu dibuat secara sah, memenuhi syarat-syarat sahnya perjanjian sebagaimana ditentukan dalam Pasal 1320 KUHPerdata.

Berdasarkan keterangan Bapak I Ketut Taman (Ketua Koperasi Simpan Pinjam Keluarga Buaji Anyar) menerangkan bahwa perjanjian yang dilakukan oleh KSP Keluarga Buaji Anyar sebagai kreditor dengan debitor wanprestasi sebagaimana disebutkan di atas, telah memenuhi persyaratan yang dimaksud oleh Pasal 1320 dan Pasal 1338 KUHPerdata, sehingga setelah terjadi tindakan wanprestasi yang dilakukan oleh debitor, maka kedua belah pihak dapat memilih penyelesaian sengketa yang akan digunakan.

Pasal 1266 KUHPerdata menyebutkan bahwa syarat batal dianggap selalu dicantumkan dalam persetujuan timbal balik, jika salah satu pihak tidak memenuhi kewajibannya. Ketentuan dari pasal tersebut sangat penting untuk mengingatkan para pihak dalam hal ini kreditor dan debitor yang membuat perjanjian dalam menyelesaikan masalahnya bahwa perjanjian harus dilaksanakan secara konsekuen oleh kedua pihak tersebut.

Pasal 1851 sampai dengan Pasal 1864 KUHPerdata tentang Perdamaian, yang menyatakan bahwa perdamaian adalah perjanjian, karenanya perjanjian perdamaian itu sah kalau dibuat memenuhi syarat-syarat sahnya perjanjian dan dibuat secara tertulis. Perdamaian dapat dilakukan di dalam Pengadilan maupun di luar pengadilan. Menurut Bapak I Ketut Taman (Ketua Koperasi Simpan Pinjam Keluarga Buaji Anyar) menerangkan bahwa penyelesaian sengketa dengan cara non litigasi, perdamaian dibuat di luar Pengadilan yang lebih ditekankan dikarenakan lebih menekan biaya yang dikeluarkan oleh koperasi dan debitur, serta pula debitur yang wanprestasi merupakan angggota dari koperasi itu sendiri.

Alternatif penyelesaian sengketa adalah penyelesaian sengketa atau beda pendapat melalui prosedur yang disepakati oleh para pihak yakni penyelesaian di luar pengadilan dengan cara konsultasi, negosiasi, mediasi, konsiliasi atau penilaian ahli. Sengketa yang terjadi antara Koperasi sebagai kreditor dengan debitor sebagai akibat dari perbuatan wanprestasi yang dilakukan oleh debitor, maka penyelesaian 
sengketa tersebut dapat dilakukan dengan beberapa cara penyelesaian sengketa non litigasi, yaitu:

a) Negoisasi yaitu upaya penyelesaian sengketa tanpa melalui proses peradilan dengan tujuan mencapai kesepakatan bersama atas dasar kerja sama yang lebih harmonis dan kreatif. Di sini para pihak berhadapan langsung dalam mendiskusikan permasalahan yang mereka hadapi dengan cara kooperatif dan saling terbuka.

Dengan kata lain negosiasi yaitu cara untuk penyelesaian masalah melalui diskusi atau musyawarah secara langsung antara pihak-pihak yang bersengketa dalam hal ini KSP Keluarga Buaji Anyar sebagai kreditor dengan debitor yang hasilnya diterima oleh kedua pihak tersebut. Negosiasi dilakukan karena 2 alasan, yaitu:

1) Mencari sesuatu yang baru yang tidak dapat dilakukannya sendiri, misalnya dalam kasus tersebut pihak kreditor dan debitor saling memerlukan untuk melakukkan perjanjian, dalam hal ini tidak terjadi sengketa;

2) Memecahkan perselisihan atau sengketa yang timbul diantara kedua pihak tersebut.

b) Mediasi adalah upaya penyelesaian sengketa para pihak dengan kesepakatan bersama melalui mediator yang bersikap netral, dan tidak membuat keputusan atau kesimpulan bagi para pihak tetapi menunjang fasilitator untuk terlaksananaya dialog antar pihak dengan suasana keterbukaan, kejujuran, dan tukar pendapat untuk tercapainya mufakat. Elemen mediasi terdiri dari:

1) Penyelesaian sengketa sukarela,

2) Intervensi atau bantuan,

3) Pihak ketiga yang tidak berpihak,

4) Pengambilan keputusan oleh para pihak secara konsensus,

5) Partisipasi aktif.

Penyelesaian sengketa melalui Mediasi tidak ada unsur paksaan antara para pihak dan mediator, karena para pihak secara sukarela meminta kepada mediator untuk membantu penyelesaian konflik yang sedang mereka hadapi. Oleh karena itu, mediator berkedudukan sebagai pembantu, walaupun ada unsur intervensi terhadap pihak-pihak yang berseteru. Dalam kondisi demikian, mediator harus bersifat netral sampai diperoleh keputusan yang hanya ditentukan oleh para pihak hanya saja dalam proses penyelesaian konflik tersebut mediator berpartisipasi aktif membantu para pihak menemukan berbagai perbedaan presepsi atau pandangan.

Mediasi adalah proses penyelesaian sengketa yang melibatkan mediator untuk membantu para pihak yang bersengketa guna mencapai penyelesaian dalam bentuk kesepakatan sukarela terhadap sebagian ataupun seluruh permasalahan yang disengketakan. Penyelesaian sengketa dengan cara mediasi yakni adanya pihak ketiga tanpa memihak pada satu pihak, yang tidak memiliki kewenangan 
mengambil keputusan tetapi membantu pihak-pihak yang bersengketa mencapai penyelesaian atau solusi yang diterima oleh kedua belah pihak yang bersengketa.

Alternatif Penyelesaian Sengketa (APS) atau non-litigasi merupakan salah satu proses untuk menyelesaikan suatu sengketa diluar pengadilan yang dapat dilakukan oleh para pihak untuk dapat menyelesaikan sengketanya (Diah, 2016). Penyelesaian Kredit Macet di Bank dapat dilakukan di luar pengadilan dengan menggunakan Alternatif Penyelesaian Sengketa (APS) atau Alternative Dispute Resolution (ADR). Penyelesaian sengketa tersebut telah memiliki dasar hukum yang kuat sejak diterbitkannya Undang-Undang Nomor 30 Tahun 1999 Tentang Arbitrase dan Alternatif Penyelesaian Sengketa.

Berdasarkan data yang diberikan oleh Bapak I Ketut Taman (Ketua Koperasi Simpan Pinjam Keluarga Buaji Anyar), penyelesaian sengketa yang dilakuakan di luar Pengadilan ini menghasilkan kesepakatan yang bersifat win-win solution atau saling menguntungkan satu sama lain yang dijamin kerahasiaan sengketa para pihak, dihindari kelambatan yang diakibatkan karena hal prosedural dan administratif, menyelesaikan masalah secara komperhensif dalam kebersamaan dan tetap menjaga hubungan baik. Penyelesaian sengketa diluar pengadilan ini lebih banyak dipilih karena proses peradilan di Indonesia dianggap tidak efisien dan tidak efektif.

Lebih lanjut Bapak I Ketut Taman (Ketua Koperasi Keluarga Buaji Anyar), menerangkan cara penyelesaian sengketa pada kasus wanprestasi yang dialami oleh KSP Keluarga Buaji Anyar dilakukan dengan cara non litigasi atau penyelesaian sengketa di luar pengadilan, baik itu dengan cara negosiasi, serta mediasi. Penyelesaian sengketa secara litigasi atau melaui jalur pengadilan dengan mengajukan gugatan terhadap debitor melalui peradilan yang berada di lingkungan peradilan umum atas tindakan wanprestasi yang dilakukan dengan tujuan untuk memperoleh haknya atas ganti rugi berupa pengembalian uang atau modal yang telah diberikan oleh KSP Keluarga Buaji Anyar serta bunga yang seharusnya dibayarkan oleh debitor.

\section{b. Penyelesaian sengketa dengan cara litigasi}

Litigasi adalah sistem penyelesaian sengketa melalui lembaga peradilan (Amarini, 2017). Sengketa yang terjadi dan diperiksa melalui jalur litigasi akan diperiksa dan diputus oleh hakim, yang mana melalui sistem ini tidak mungkin akan dicapai sebuah win-win solution atau solusi yang memperhatikan kedua belah pihak karena hakim harus menjatuhkan putusan dimana salah satu pihak akan menjadi pihak yang menang dan pihak lain menjadi pihak yang kalah. Proses penyelesaian sengketa melalui jalur litigasi ini dapat dilakukan dengan mengajukan gugatan terhadap debitor melalui peradilan yang berada di lingkungan peradilan umum jika tidak ditemukan kesepakatan penyelesaian sengketa antara kreditor dengan para debitor yang wanprestasi dengan cara non litigasi atau di luar pengadilan.

Berdasarkan data yang diberikan oleh Bapak I Ketut Taman (Ketua Koperasi Keluarga Buaji Anyar), penyelesaian secara litigasi, penyelesaian pinjaman terhadap debitor wanprestasi dapat dilakukan dengan cara mengajukan gugatan ke 
pengadilan Negeri Denpasar sesuai dengan ketentuan hukum acara perdata. Dengan cara tersebut dapat dijadikan salah satu cara penyelesaian pinjaman macet dengan gugatan perdata atas dasar wanprestasi. Mengajukan gugatan perdata melalui Pengadilan Negeri (PN) atas dasar wanprestasi (ingkar janji) dapat dijadikan opsi oleh koperasi selaku kreidtor untuk menyelesaikan pinjaman macet dengan debitor. Opsi ini dapat ditempuh karena pihak koperasi (kreditor) tidak dapat melakukan eksekusi grosse akta melalui Pengadilan Negeri disebabkan antara lain perjanjian kreditnya tidak diiringi pembuatan grosse akta pengakuan utang yang dibuat secara notariil.

Berdasarkan uraian tersebut diatas maka teori yang digunakan untuk menganalisis pembahasan ini adalah Teori Perlindungan Hukum menurut Menurut Philipus M. Hadjon perlindungan hukum bagi rakyat dapat dibagi menjadi dua macam yaitu pertama, perlindungan hukum preventif dan kedua perlindungan hukum represif (Hadjon, 2007: 25). Perlindungan hukum preventif, rakyat diberikan kesempatan untuk mengajukan keberatan (inspraak) atau pendapatnya sebelum suatu keputusan pemerintah mendapat bentuk defenitif, artinya perlindungan hukum yang preventif bertujuan untuk mencegah terjadinya sengketa.

Perlindungan hukum preventif sebenarnya sudah diberikan oleh pemerintah yang tertuang di dalam UUJF yang terdapat dalam Pasal 11 tentang pendaftaran jaminan fidusia. Dengan dilakukannya pendaftaran maka koperasi akan diberikan tentang kepastian hukum yang erat kaitannya dengan perlindungan terhadap koperasi apabila terjadi sengketa di kemudian hari oleh para pihak. Di dalam permasalahan perkoperasian di Denpasar maka perlindungan preventif dapat diberikan oleh koperasi terhadap debitur yang mengalami kredit macet, yakni dengan diberikannya opsi upaya hukum non litigasi seperti mediasi dan negoisasi. Upaya non litigasi tersebut merupakan salah satu upaya untuk menyelesaikan permasalahan koperasi dengan debiturnya yang mana dengan mediasi dan negoisasi maka pihak koperasi memberikan suatu kepentingan yang sama atau sifatnya saling menguntungkan antara kreditur dan debitur. Perlindungan hukum represif bertujuan untuk menyelesaikan sengketa, yang mana dalam permasalahan yang terjadi antara koperasi dan debiturnya maka pihak koperasi akan melakukan upaya litigasi dengan mengajukan gugatan ke pengadilan atas dasar wanprestasi yang dilakukan oleh debitur.

\section{Kesimpulan}

Berdasarkan hasil pembahasan pada bab-bab sebelumnya, dapat disimpulkan jawaban dari pokok permasalaham dalam penulisan tesis ini, yaitu: Pelaksanaan eksekusi benda jaminan dengan jaminan fidusia pada Koperasi, yakni debitur wanprestasi (ingkar janji), pihak koperasi melakukan penyitaan terhadap objek jaminan, pengambilalihan atau pencairan objek jaminan secara dibawah tangan, serta pelelangan terhadap objek jaminan berdasarkan Surat Kuasa Menjual. Hasil penjualan setelah dikurangi biaya-biaya untuk melaksanakan penjualan tersebut, menggunakan sisanya untuk membayar utang debitur kepada Koperasi, dan apabila ada kelebihan maka Koperasi akan menyerahkan atau mengembalikan kelebihan 
tersebut kepada debitur. Upaya hukum yang dilakukan kreditur jika eksekusi terhadap benda bergerak yang tidak dibebani Jaminan Fidusia tidak dapat dilaksanakan yaitu pihak koperasi selaku kreditur menempuh jalur non litigasi yakni negosiasi dan mediasi. Opsi lain jalur non litigasi tidak membuahkan hasil, yakni pihak koperasi menempuh jalur litigasi dengan mengajukan gugatan ke pengadilan atas dasar wanprestasi (ingkar janji) yang dilakukan oleh debitur.

\section{Daftar Referensi}

Adiyanta, F. C. S. (2019). Hukum dan Studi Penelitian Empiris: Penggunaan Metode Survey Sebagai Instrumen Penelitian Hukum Empiris. Adminitrative Law $\mathcal{E}$ Governance Journal, 2(4), 697-709.

Agnes, I. (2009). Eksekusi Jaminan Fidusia Yang Tidak Didaftarkan Ke Kantor Pendaftaran Fidusia (Studi Kasus Di PT. BPR Arthaprima Danajasa Bekasi). Universitas Diponegoro.

Amarini, I. (2017). Penyelesaian Sengketa Yang Efektif Dan Efisien Melalui Optimalisasi Mediasi Di Pengadilan. Kosmik Hukum, 16(2), 87-106.

Bahsan, M. (2012). Hukum Jaminan dan Jaminan Kredit Perbankan Indonesia. Rajawali Pers.

Diah, M. M. (2016). Prinsip dan Bentuk-Bentuk Alternatif Penyelesaian Sengketa Di Luar Pengadilan. Jurnal Ilmiah Hukum Dan Dinamika Masyarakat, 5(2), 111-122.

Fuady, M. (2014). Konsep Hukum Perdata. Raja Grafindo Persada.

Hadjon, P. M. (2007). Perlindungan Hukum Bagi Rakyat Indonesia: Sebuah Studi Tentang Prinsip-Prinsipnya, Penanganannya Oleh Pengadilan Dalam Lingkungan Peradilan Umum Dan Pembentukan Peradilan Administrasi. Peradaban.

Kurniawan, I. G. H. (2013). Tindakan Koperasi Simpan Pinjam Yan Mengakibatkan Perbuatan Tindak Pidana. Lex Jurnalica, 10(1), 1-7.

Manurung, D. R. N. N. (2015). Perlindungan Hukum Debitur Terhadap Parate Eksekusi Obyek Jaminan Fidusia. Universitas Tadulako.

Marbun, S., Mulyadi, M., Suhaidi, S., \& Siregar, M. (2015). Perbedaan Antara Wanprestasi Dan Delik Penipuan Dalam Hubungan Perjanjian. USU Law Journal, 3(2), 126-137.

Nasution, B. J. (2014). Negara Hukum dan Hak Asasi Manusia. Mandar Maju.

Patrik, P. (1998). Hukum Perdata II. Sinar Grafika.

Prodjodikoro, R. W. (2004). Asas-Asas Hukum Perjanjian. Mandar Maju.

Sembiring, J. J. (2011). Cara Menyelesaikan Sengketa di Luar Pengadilan. Visimedia.

Setyorini, A. (2017). Akibat Hukum Perjanjian Pembiayaan Konsumen dengan Pembebanan Jaminan Fidusia yang Tidak Didaftarkan. Universitas 17 Agustus 1945 Surabaya.

Slamet, S. R. (2013). Tuntutan Ganti Rugi Dalam Perbuatan Melawan Hukum: Suatu 
Perbandingan Dengan Wanprestasi. Lex Jurnalica, 10(2), 107-120.

Wahyuni, D. T. (2011). Standar Penanganan Pinjaman Bermasalah Pada Koperasi Simpan Pinjam Sarana Aneka JASA. Universitas Sebelas Maret.

Wibowo, A. T. (2013). Analisis Prosedur Pemberian Kredit pada UED-SP Sumber Makmur Kecamatan Tambang Kabupaten Kampar Untuk Menekan Terjadinya Kredit Macet. Universitas Islam Negeri Sultan Syarif Kasim.

Widjaja, G., \& Yani, A. (2000). Jaminan Fidusia. Raja Grafindo Persada.

Zaeni, A. (2005). Hukum Bisnis Prinsip dan Pelaksanaannya di Indonesia. Raja Grafindo Persada. 